\title{
DETERMINATION OF WORKLOADS IN CUTTING HEAD OF LONGWALL TUMBLE HEADING MACHINE
}

\author{
Witold BIAtY \\ Silesian University of Technology
}

\begin{abstract}
:
The mining organ of the longwall heading machine KGS-320 with radial tools was the subject of the analysis. Cooperation of single knife with the mined solid rock was estimated in order to determine values of the forces and moments that might occur in the mining process and to estimate the energy consumption of the mining process. Analogous determination of forces and moments values as well as energy consumption of the mining process for the whole mining organ with regard to all the knives installed.

Following the thorough analysis of the solid rock mining process with the longwall tumble heading machine mining head the PC computer program simulating such organ's mode of action has been developed. This program presents the simulation of the mining process in the part regarding direct contact of the cutting tool (knife) with the rock mass.

The result of this simulation is force and moments distribution, which are transmitted via the mining organ (head) during one full turn $\left(360^{\circ}\right)$ and, as consequence, via whole longwall heading machine.
\end{abstract}

Key words: mining, longwall tumble heading machine's mining head, energy consumption of the mining process

\section{INTRODUCTION}

Poland's access to the United Europe's markets requires economic and technical improvement also in the coal mining industry with broader search for more effective methods allowing higher output concentration and lower costs level resulting in positive accumulation $[7,9,13]$.

In Polish mining industry coal exploitation takes place mainly by wall systems via mechanical mining with the use of longwall tumble heading machines. The increase in coal output in mines is correlated with mining range expansion with already existing tumble heading machines to hard mined coals [3].

The development of coal mining mechanization is mainly directed by:

- high output concentration,

- working place reduction,

- increase in economic efficiency of production.

Technical development of mechanical mining machines (longwall tumble heading machines) as well as their application in given conditions has already been solved, and the mining process with the use of these machines is more effective than other methods. Other, unconventional mining methods where the processes take place in laboratory or semi-industrial conditions bring unsatisfactory results due to high energy consumption or technical difficulties in given mining conditions $[2,5]$. Then, it can be stated that mechanical mining will dominate Polish and world mining industry.

In order to face the progress and economic conditions the effectiveness of mechanical mining machines' utilization should increase by:
- decrease of energy consumption of the mining process,

- increase of tools' and mining organs' durability and reliability,

- improvement of energy transmission from the engine to the mining organ,

- automation of the mining process,

- improvement of operators' safety and working conditions.

Constant development of coal layers' mining mechanization, application of tumble heading machines with various mining heads and increasing power installed require the classification and evaluation of coal seams with regard to their mineability. This would allow for proper selection of mining machines to given mining conditions and technological forecasting of energy consumption of the mining process i.e. power demand.

Therefore the need of constant improvement of research means and methods leading to determination of total mined coal material's resistances during its disintegration, i.e. to determination tumble heading machine's power necessary to mine in given mining-geological conditions with pre-set advance speed.

\section{BRIEF DESCRIPTION OF PROBLEM}

In Polish mining industry mechanical excavation of coal seams with the use of longwall tumble coal miners is applied.

In order to consider the whole complexity of the problem the mining process should be regarded as interaction between the solid rock and the mining machine. 
The mining, i.e. separation of coal pieces from the solid rock with the use of a knife or set of knives placed on the mining organ, is a result of composition of two tumble heading machine mining head's motions - rotation and translation.

We assume that the main motion is rotation of the mining organ, defined as cutting velocity, while the translation of the whole longwall heading machine is a supporting motion. Independently from the exploitation system and mining-geological conditions three basic phases of organ's action can be distinguished:

- phase I - normal work. The most often. The mining organ works with full web with constant mining height whereas the advance of the mining organ is a result of the longwall heading machine's velocity,

- phase II - slotting. This is the preliminary mode of action of the mining machine taking place at the beginning of the mining cycle. In this case the advance velocity as well as the mining height are equal to normal mode whereas the working area of the mining machine varies from zero to maximum value,

- phase III - related to elevation or depression of the mining organ. It occurs during mining height modification. In this phase the longwall heading machine stands still while the arm translocation operator is activated.

It could be said that readily mined coals' mining modes are depleted, and we have to face the problem of currently applied machinery readjustment to harder mineability conditions.

The mining conditions consist of:

- mining-geological conditions of strata deposition including mineability,

- placement and arrangement of cutting tools,

- tools' shape and their cooperation,

- grindability,

- machines' durability and reliability,

- energy consumption in the mining process.

The above are some of the factors (very vital though) characterizing the efficacy of the mechanical mining with the use of the longwall tumble coal miner.

Constant tendency to concentrate the excavation on one longwall leads to pile up of large amount of machines and device, equipped with high-power motors, in one place $[12,13]$.

In Poland, a high excavation concentration heading is a heading where a mean daily output in a given month is approximately 5000 tons a day [11]. This kind of activity leads to fast mining advance which not always is in accordance with other activity directions as: reaching increased portion of thicker excavated size grade, or decreased energy consumption of the mining process. These activities are constantly related; decrease in overgrinding leads to decrease in energy consumption, whereas the enrichment process of the thicker assortment is cheaper which brings higher profit.

With regard to the above, improvement in the following factors:

- head advance,

- output,

- tool wear per mined tons,

- total cost of the output of 1 (one) Mg of coal,

shall be reached by multiple actions, including the very important as improvement in selection methods of longwall heading machines. These operations regard not only the construction sphere but also the basic research on mechanisms accompanying the mining process.

The construction process must relate to the full range of the basic research, leading to construction of more effective, durable and dependable machines and technical improvement of optimal mining parameters selection.

The mining process study, especially in difficult mininggeological conditions have proved that in order to set the range of the tumble mining heading machines application the so called decisive coal properties should be defined.

Following Bialy $[4,5]$ and Borycz and Koziel [6] the decisive coal properties include:

- mineability, represented by mineability index $A_{\psi}$, or $\mathrm{WU}_{\mathrm{B}} \mathrm{kN} / \mathrm{m}$,

- exploitation pressure represented by vertical component of the stress state $\sigma_{z} \mathrm{MPa}$,

- energy consumption of the mining process $E_{U} \mathrm{MJ} / \mathrm{m}^{3}$.

The above properties determine the technique and technology of the exploitation process. These factors determine the mining productivity fundamentally by precising the efficacy of the mining machines.

The construction and selection of the machines mining organs should be based upon the above factors.

\section{MINING ORGANS OPERATION ANALYSIS}

The machines applied in underground mining include:

- mechanical coal miners,

- heading machines,

- tunnel drivers.

The analysis of the mining machines organs of various constructions allows for arrangement and division of working geometry of these organs into four major groups:

- group I (Fig. 1a) - mechanical coal miners' mining organs,

- group II (Fig. 1b) - mining organs of cutter gib heading machines with the mining organ rotating around the cutter gib's axis and advance parallel to the cutter's axis (type 1),

- group III (Fig. 1c) - mining organs of cutter gib heading machines with the mining organ rotating around the cutter gib's axis and advance normal to the cutter's axis (type 2),

- group IV (Fig. 1d) - tunnel drivers' mining organs.
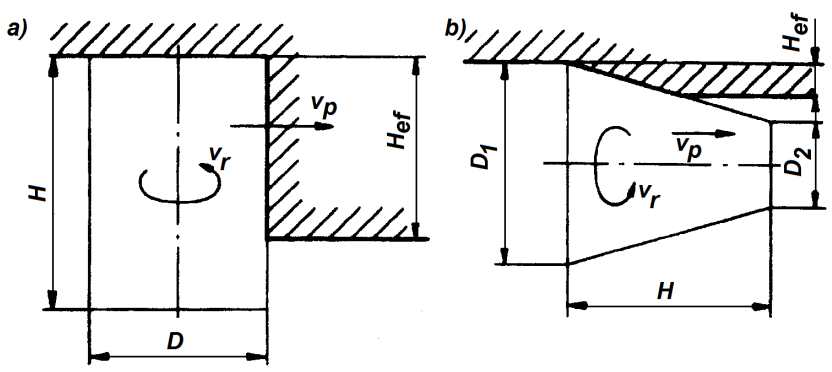

c)

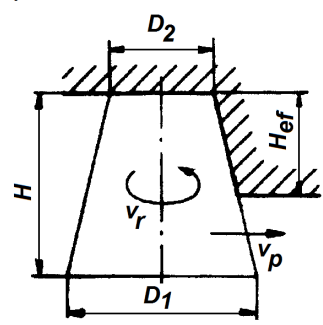

d)

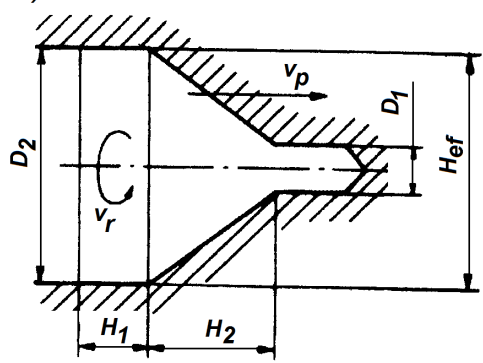

Fig. 1 The mining machines organs of various constructions 
This paper presents the analysis of the group I mining organ's - after Bialy [1, 2], and Vasek, Slavik and Gondek [14] - geometry of action, i.e. longwall tumble coal miner (Fig. 1a).

The heading machine is a team machine carrying out many operations simultaneously (mining and loading).

With regard to the longwall tumble coal miners (which are nowadays the only produced and applied) two basic types are distinguished:

- KWB type,

- KGS, KGE, KSW type.

This type of the mining organ may turn bi-directly (Fig. $2 a$ ), as well as advance in four directions (Fig. $2 b, c$ ).
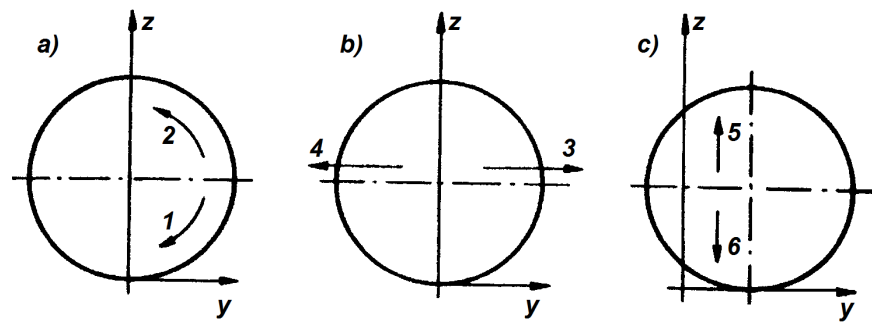

Fig. 2 Turn and advance directions of longwall tumble coal miner's mining organ

The mining organ's mode of action is defined as penetration of the organ, along with the knife placed on it, into the mined solid coal - the mining organ is winning different height ( $m_{\text {ef }}$ varies from 0 to $D$ ),

Following cases are distinguished in this process:

- the mining organ starts the excavation on the web depth value 0 up to value $h$ (Fig. 3a,b),

- the mining organ is digging through one or more layers of different coal types or inclusions (Fig. 3c,d).
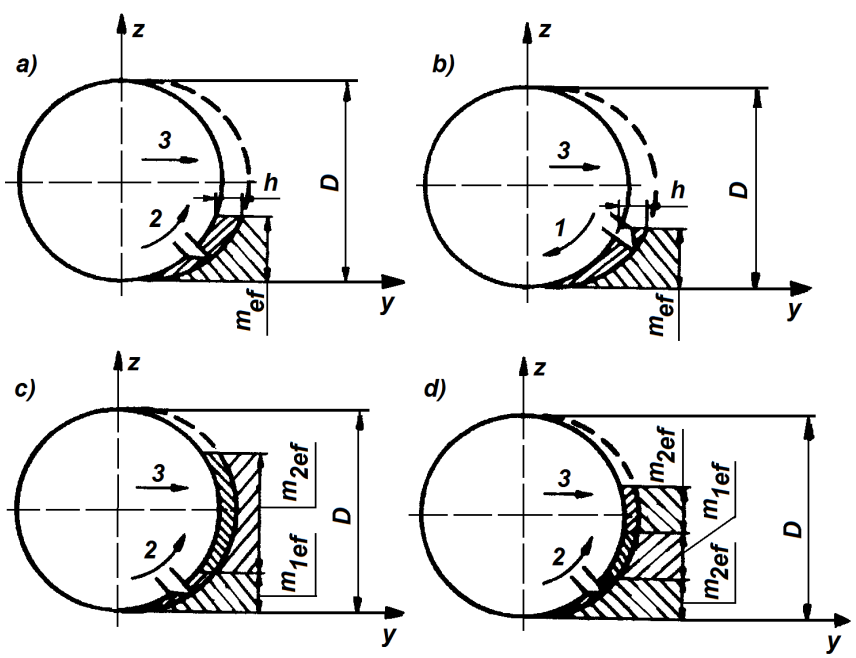

Fig. 3 The solid rock mining process

The mining process realized by the mining organ of the tumble coal miner is a process of separation of coal parts from the solid rock with the use of the cutting tools (knives). As a result of this operation we obtain slices- as many as the amount of knives placed on the mining organ.

The slice with characteristic data as a result of one knife's cut in tri-dimensional co-ordinate system is presented on Figure 4.

The height of the mined solid coal $\left(m_{\text {ef }}\right.$, Fig. 3$)$ varies from 0 to value $D$ as the mining organ penetrates the solid coal rotating along its axis.

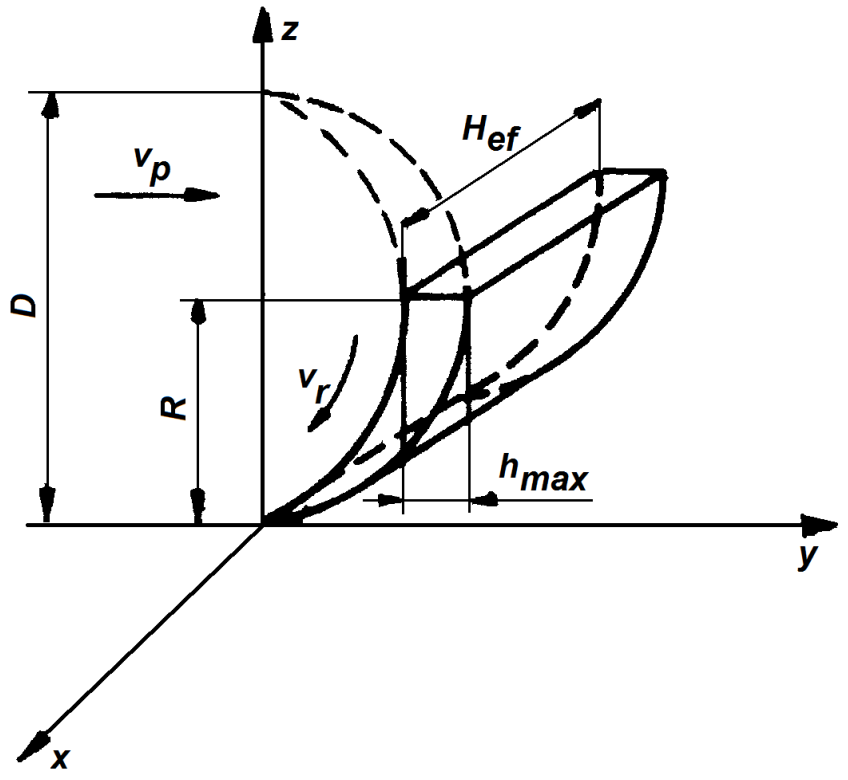

Fig. 4 Single cut in the tri-axial co-ordinate system

\section{ESTIMATION OF FORCE AND MOMENTS VALUES ON THE MINING HEAD}

The mining organ is getting the solid coal with the use of cutting tools - the knives placed on it.

Due to the fact, that the mining organ is the most important element in the process of selection of the longwall complex it is very important that it satisfies all requirements of the complex. The estimation of the force and moments values on the mining organ as well as their variability in the working mode (one full turn) is very important then.

The subject of this analysis is estimation of the values occurring during the longwall tumble coal miner KGS-320 mining organ's action with radial knives placed on it. The cutting tools, called miner's knives, are replaceable elements mounted in holders welded on the mining organ. When describing the knives placement geometry on the mining organ a set: knife- knife's holder is considered.

The geometry of the mining organ of the longwall tumble coal miner (Fig. 5) is described by following parameters:

- the amount of knives on the mining organ - X pcs,

- the distance from the knife's edge to the axis of the mining organ - $\mathrm{R} \mathrm{mm}$,

- the distance from the knife's edge to the yz plane - $x \mathrm{~mm}$,

- the knife's placement circumferential angle - $\phi^{\circ}$,

- the knife's angle of rotation related to the drum's (mining organ) axis $-\beta_{1}{ }^{\circ}$,

- the knife's angle of inclination - $\alpha_{1}{ }^{\circ}$,

- the knife edge's angle of rotation $-\nu_{1}{ }^{0}$,

- the knife's length - 1 (one) mm.

The cooperation between single knife and the mined solid coal has been analyzed. Consequently, forces' and moments' values as well as mining head's load (of the whole mining organ from all installed knives) was estimated. The longwall tumble coal miner's mining head's load means resultant forces and moments occurring on the mining head at one full turn $\left(360^{\circ}\right)$.

The forces resulting from rock mass reaction press (concentrated in one point) one knife of the mining organ, which is under influence of the load resulting from the rock mass reaction on blade's penetration. 

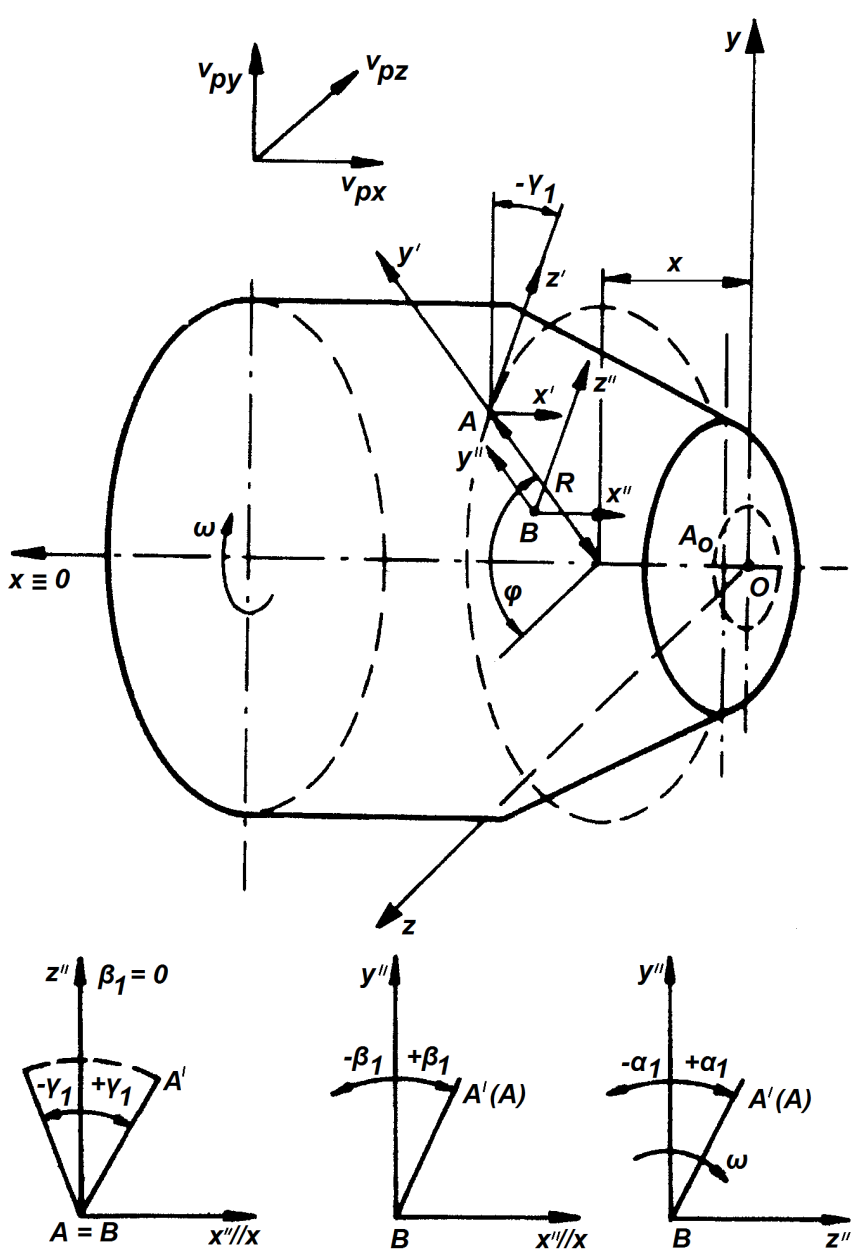

Fig. 5 Geometry of the longwall tumble coal miner's mining organ

Three perpendicular forces describe the knife's load (Fig. 6):

$\mathrm{F}_{\mathrm{t}}$ - cutting force,

$\mathrm{F}_{\mathrm{n}}$ - clamp force to the mined solid coal,

$F_{b}$ - side (thrust) force.

The direction of $F_{t}$ force overlaps the instantaneous direction of tangent to the motion path (cycloid) of knife's blade edge. The $F_{n}$ force direction is normal to $F_{t}$ force direction and is consistent with direction of line connecting the knife's blade edge to the beginning of the co-ordinate system, while the direction of $F_{b}$ force is normal to the plane formed by $F_{t}$ and $F_{n}$ forces. The knife's orientation is described by angle $\phi$, while the inclination angle $\beta_{1}$ of knife's edge in horizontal plane allows considering the solid rock's reaction with helical plane of the mining organ (semi-axial force occurrence). All the components of resultant reaction of cutting force $F_{t}$ have been considered, as well as the clamp force $F_{n}$ resulting from incising of the mining head into the solid rock. This reaction is not related with the mining organ's rotation therefore it has been accepted that component $F_{n}$ of the force in relation to the helical plane of the mining organ.

During the longwall tumble coal miner mining organ's action the solid coal is mined by given amount of knives. During one full turn of the mining head this amount varies as a result of entering and leaving the mined solid coal by given knives. Each entering knife deepening into the solid coal makes a cut.
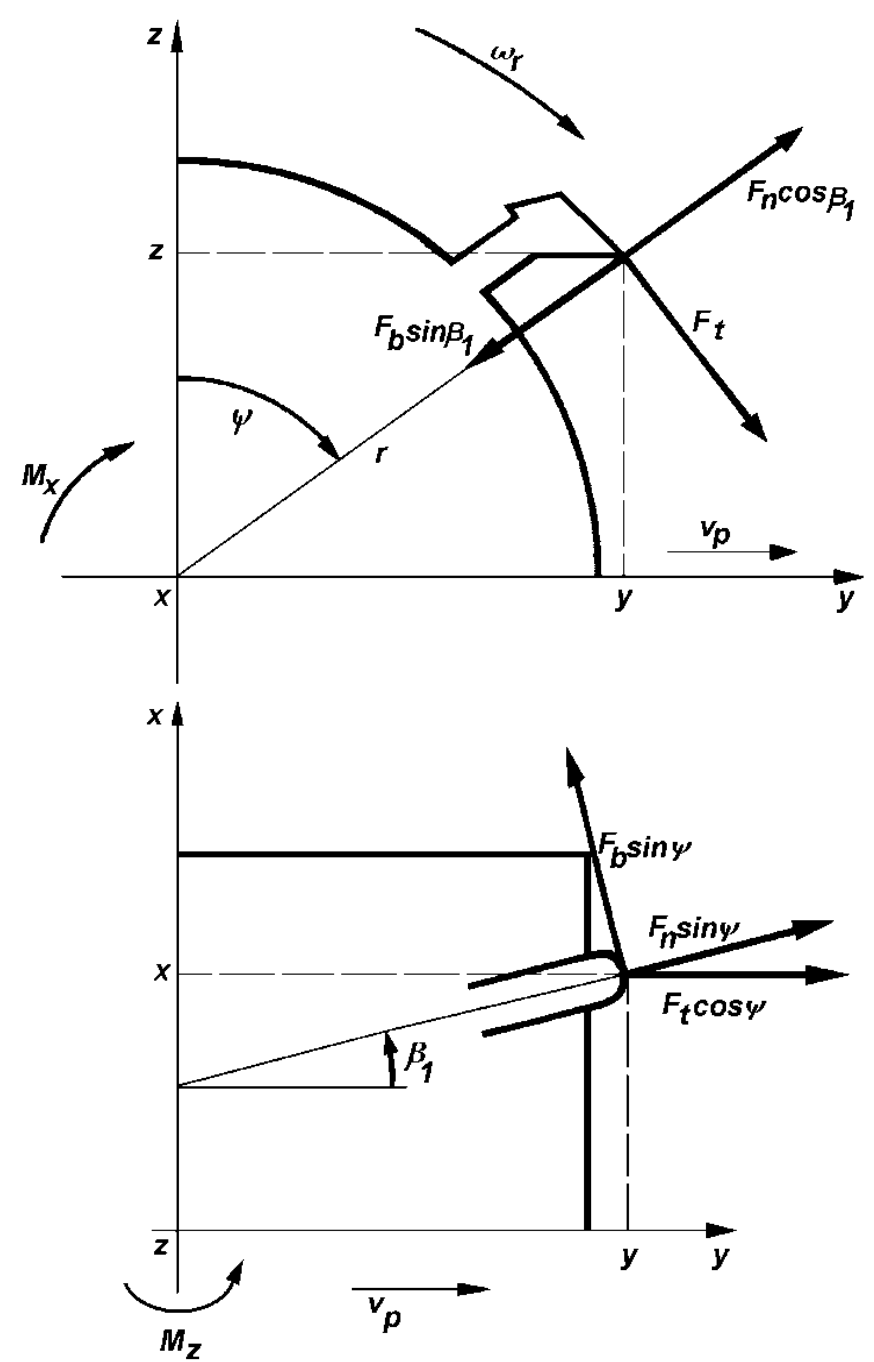

Fig. 6 Characteristics of knife's blade forces

The size and shape of the cut depend on:

- the properties of the mined coal,

- the situation of the cutting knife related to the preceding knife,

- coal miner's parameters; the web, angular velocity of the mining head, advance speed, mining height.

The forces, as well as the moments operating on a single knife and on the whole mining organ in given planes are presented on Figures 6 and 7.

Forces values (Fig. 6) are as follows:

$$
F_{t}=\left(F_{t}^{x} ; F_{t}^{y} ; F_{t}^{z}\right)=\left(0 ;-F_{t} \cos \phi ; F_{t} \sin \phi\right)
$$

$F_{n}=\left(F_{n}{ }^{x} ; F_{n}{ }^{y} ; F_{n}{ }^{z}\right)=\left(-F_{n} \sin \phi \sin \beta_{1} ;-F_{n} \sin \phi \cos \beta_{1} ;-\right.$

$$
\left(-F_{n} \cos \phi \sin \beta_{1}\right)
$$

$$
\begin{gathered}
F_{b}=\left(F_{b}{ }^{x} ; F_{b}{ }^{y} ; F_{b}{ }^{z}\right)=\left(-F_{n} \cos \beta_{1} ; F_{b} \sin \phi \sin \beta_{1}\right. \\
\left.F_{b} \cos \phi \sin \beta_{1}\right)
\end{gathered}
$$

In order to determine the forces moment's values related to given axes of the system, the sum of all forces components related to given axes of the selected co-ordinate system needs to be determined. 
These forces values are as follows:

$$
\begin{aligned}
& F_{x}=F_{t}^{x}+F_{n}^{x}+F_{b}^{x} \\
& F_{y}=F_{t}^{y}+F_{n}^{y}+F_{b}^{y} \\
& F_{z}=F_{t}^{z}+F_{n}{ }^{z}+F_{b}{ }^{z}
\end{aligned}
$$

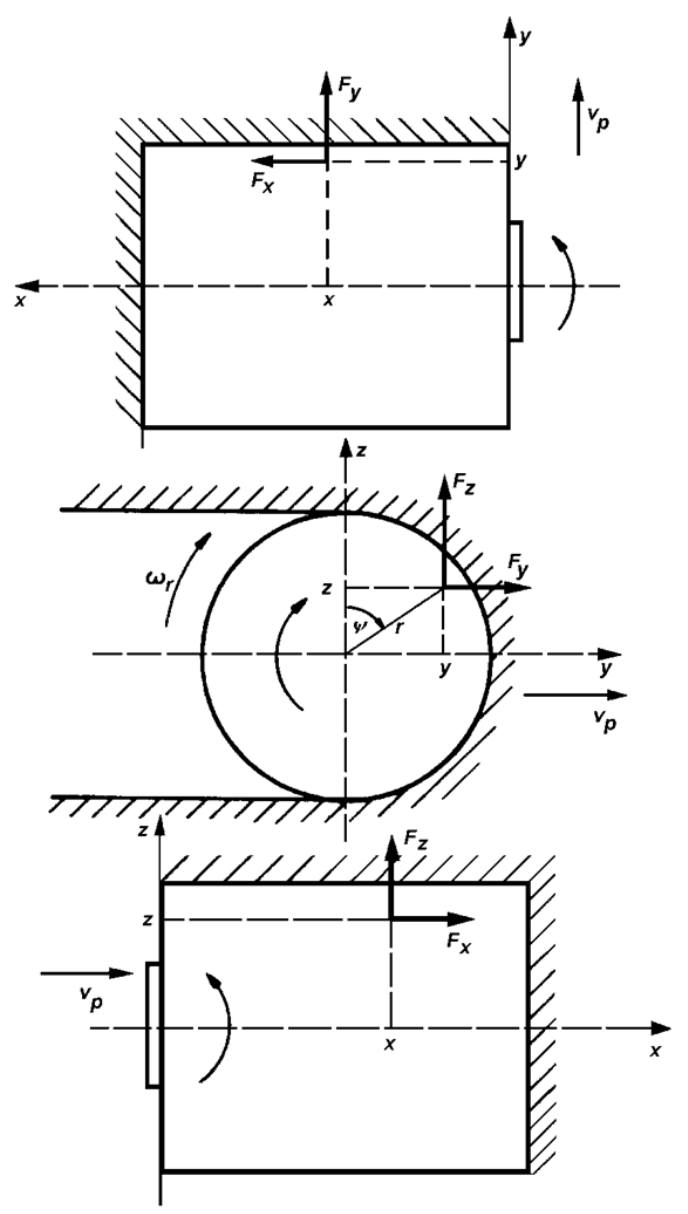

Fig. 7 The mining head's forces characteristics

Inserting the proper values of the coordinates we obtain:

$$
\begin{gathered}
F_{x}=\left(-F_{n} \sin \phi \sin \beta_{1}-F_{b} \cos \beta_{1}\right) \\
F_{y}=\left(-F_{t} \cos \phi-F_{n} \cos \phi \sin \beta_{1}+F_{b} \cos \phi \sin \beta_{1}\right) \\
F_{z}=\left(F_{t} \sin \phi-F_{n} \cos \phi \sin \beta_{1}+F_{b} \cos \phi \sin \beta_{1}\right)
\end{gathered}
$$

The moments' values (Fig. 8) are as follows:

$$
\begin{aligned}
& M_{x}=F_{z} y-F_{y} z \\
& M_{y}=F_{z} z-F_{y} x \\
& M_{z}=F_{y} z-F_{x} y
\end{aligned}
$$

Finally, the moments related to given axes are as follows:

$$
\begin{aligned}
& M_{x}=\left(F_{t} \sin \phi-F_{n} \cos \phi \sin \beta_{1}+F_{b} \cos \phi \sin \beta_{1}\right) y- \\
& -\left(-F_{t} \cos \phi-F_{n} \sin \phi \cos \beta_{1}+F_{b} \sin \phi \sin \beta_{1}\right) z
\end{aligned}
$$

$$
\begin{gathered}
M_{y}=\left(-F_{n} \sin \phi \sin \beta_{1}-F_{b} \cos \beta_{1}\right) z- \\
-\left(F_{t} \sin \phi-F_{n} \cos \phi \sin \beta_{1}+F_{b} \cos \phi \sin \beta_{1}\right) x \\
M_{z}=\left(-F_{t} \cos -F_{n} \sin \phi \cos \beta_{1}+F_{b} \sin \phi \sin \beta_{1}\right) x- \\
-\left(-F_{n} \sin \phi \sin \beta_{1}-F_{b} \cos \beta_{1}\right) y
\end{gathered}
$$

The forces and moments values which might occur on the mining head equipped with knives, equal the sum of forces and moments resulting from the load of all knives situated in a given moment in the mined coal. The above model of longwall tumble coal miner's mining head's loading and the method of forces and moments estimation is so complicated that its practical application requires special computer calculating program with computer operating system.

\section{MINING PROCESS MODELLING}

The requirements related with the mining organ's operation make necessary finding of such tools that would make this process easier. Starting with the design process or selection from the already existing organs, the influence of many factors should be undertaken. Therefore, a very vital task is a possibility of quick selection of the proper organ, with regard to fast and easy check whether an organ would operate properly in given conditions. In order to reach this aim a specialist computer program has been developed, which allows estimating all previously established values.

After detailed analysis of the solid coal mining process with the use of the longwall tumble miner's mining head a PC computer program simulating such organ's mode of action has been developed. This program presents the simulation of the mining process in the part regarding direct contact of the cutting tool (knife) with the solid coal.

The result of this situation is a scheme of cutting and analysis of forces and moments that are transmitted by the mining organ (head) during its one full turn $\left(360^{\circ}\right)$ and consequently by the whole coal miner.

In order to present the forces and moments values occurring at one full turn of the coal miner's head the mode of action of a single knife has been described.

The following are the results of the mining resistance overcoming:

- cutting force $F_{t}$,

- clamping force to the mined solid coal $F_{n}$,

- knife's clamping force (passive pressure force) $F_{b}$.

Composition of single knives forces and moments' values leads to obtaining total forces and moments' values of all the knives placed on the mining head. Obtained forces and moments values allow analyzing of the variable mode of action of the mining organ during its one full turn, i.e. the dynamics of the mining process. The actual web areas of given knives have also been determined presenting instantaneous pressures of the given knives during the mining process. The volume of the mined coal was determined as well which is the value strongly influencing the energy consumption of the mining process.

During mining process modeling following assumptions have been made:

- mining velocity $v_{r}$ and advance speed $v_{p}$ are constant ( $k=$ const),

- mining organ operates on the full height $\mathrm{H}$, which is allowed by its construction, 
- the mined coal over the whole height and length of the longwall is homogenous (is characterized by the constant value of the mineability index $A$ ).

\section{CALCULATIONS RESULTS}

With the application of the developed simulating program the scheme of mining with the use of the mining head of KGS-320 coal miner at its one full turn $\left(360^{\circ}\right)$ was presented.

Table 1 presents the data resulting from the longwall tumble coal miner's mining organ's geometry (with respect to description in chapter 4).

To perform the calculations following parametrs of the coal miner have been accepted;

Knives type - radial - RAPID 83/3, quantity 38,

Knife's width $20 \mathrm{~mm}$, knife's radius $22 \mathrm{~mm}$,

Mineability index $A_{\psi}=3.36 \mathrm{kN} / \mathrm{m}$

Side-crumble angle $\psi=60^{\circ}$,
Mining organ's diameter $\mathrm{H}=1446 \mathrm{~mm}$

Web depth $-650 \mathrm{~mm}$,

Mining head's rotational speed $v_{r}=40$ cycles $/ \mathrm{min}$

Coal miner's advance speed $v_{p}=3 \mathrm{~m} / \mathrm{min}$.

Knives' placement:

0 - cutting disk,

$1,2,3,4$-consecutive helical lines on the longwall tumble coal miner's mining head.

With regard to the method and algorism of calculations pre-set the scheme of cutting forces and moments course on the mining organ during its one full turn $\left(360^{\circ}\right)$ was estimated (Table 2, 3, 4, Fig. 8 to 11).

Following have also been estimated:

- web areas of given knives,

- loosening line's length for given knives,

- mined volume $V$ at one full turn.

- mean values of forces and moments during one full $\operatorname{turn}\left(360^{\circ}\right)$.

Table 1

Nine degree scale for assessing significance between paired elements

\begin{tabular}{|c|c|c|c|c|c|c|c|c|c|c|c|}
\hline $\begin{array}{c}\text { Knife } \\
\text { No }\end{array}$ & $\begin{array}{c}\mathrm{R} \\
\mathrm{mm}\end{array}$ & $\begin{array}{c}X \\
\mathrm{~mm}\end{array}$ & $\phi^{\circ}$ & $\beta^{\circ}$ & $\begin{array}{c}\text { Knife } \\
\text { placement }\end{array}$ & $\begin{array}{c}\text { Knife } \\
\text { No }\end{array}$ & $\begin{array}{c}\mathrm{R} \\
\mathrm{mm}\end{array}$ & $\begin{array}{c}\mathrm{X} \\
\mathrm{mm}\end{array}$ & $\phi^{\circ}$ & $\beta^{\circ}$ & $\begin{array}{c}\text { Knife } \\
\text { placement }\end{array}$ \\
\hline 1 & 795 & 54 & 31 & -15 & 0 & 20 & 800 & 430 & 86 & 0 & 1 \\
\hline 2 & 785 & 28 & 48 & -27 & 0 & 21 & 800 & 520 & 103 & 0 & 1 \\
\hline 3 & 770 & 0 & 65 & -42 & 0 & 22 & 800 & 595 & 120 & 0 & 1 \\
\hline 4 & 795 & 115 & 82 & 17 & 0 & 23 & 800 & 475 & 0 & 0 & 4 \\
\hline 5 & 795 & 54 & 117 & -15 & 0 & 24 & 800 & 565 & 19 & 0 & 4 \\
\hline 6 & 785 & 28 & 135 & -27 & 0 & 25 & 800 & 205 & 128 & 0 & 2 \\
\hline 7 & 770 & 0 & 155 & -42 & 0 & 26 & 800 & 295 & 144 & 0 & 2 \\
\hline 8 & 800 & 87 & 171 & 0 & 0 & 27 & 800 & 385 & 167 & 0 & 2 \\
\hline 9 & 795 & 54 & 211 & -15 & 0 & 28 & 800 & 475 & 185 & 0 & 2 \\
\hline 10 & 785 & 28 & 226 & -27 & 0 & 29 & 800 & 565 & 200 & 0 & 2 \\
\hline 11 & 770 & 0 & 245 & -42 & 0 & 30 & 800 & 160 & 209 & 0 & 3 \\
\hline 12 & 800 & 87 & 262 & 0 & 0 & 31 & 800 & 250 & 225 & 0 & 3 \\
\hline 13 & 795 & 115 & 297 & 17 & 0 & 32 & 800 & 340 & 247 & 0 & 3 \\
\hline 14 & 785 & 28 & 315 & -27 & 0 & 33 & 800 & 430 & 266 & 0 & 3 \\
\hline 15 & 770 & 0 & 333 & -42 & 0 & 34 & 800 & 520 & 285 & 0 & 3 \\
\hline 16 & 800 & 87 & 351 & 0 & 0 & 35 & 800 & 595 & 300 & 0 & 3 \\
\hline 17 & 800 & 160 & 28 & 0 & 0 & 36 & 800 & 205 & 309 & 0 & 4 \\
\hline 18 & 800 & 250 & 47 & 0 & 1 & 37 & 800 & 295 & 328 & 0 & 4 \\
\hline 19 & 800 & 340 & 66 & 0 & 1 & 38 & 800 & 385 & 346 & 0 & 4 \\
\hline
\end{tabular}


Table 2

Web areas and loosening lines' length of the knives

\begin{tabular}{|c|c|c|c|c|c|}
\hline $\begin{array}{l}\text { Knife } \\
\text { No. }\end{array}$ & $\begin{array}{c}\text { Web area } \\
\mathrm{mm}^{2}\end{array}$ & $\begin{array}{l}\text { Loosening line } \\
\text { length } \mathrm{mm}\end{array}$ & $\begin{array}{l}\text { Knife } \\
\text { No. }\end{array}$ & $\begin{array}{c}\text { Web area } \\
\mathrm{mm}^{2}\end{array}$ & $\begin{array}{l}\text { Loosening line } \\
\text { length } \mathrm{mm}\end{array}$ \\
\hline 1 & 1510 & 126 & 20 & 1742 & 85 \\
\hline 2 & 802 & 99 & 21 & 1702 & 82 \\
\hline 3 & 155 & 34 & 22 & 4727 & 170 \\
\hline 4 & 842 & 73 & 23 & 1624 & 81 \\
\hline 5 & 1708 & 134 & 24 & 1358 & 78 \\
\hline 6 & 828 & 99 & 25 & 1703 & 83 \\
\hline 7 & 163 & 38 & 26 & 1681 & 82 \\
\hline 8 & 1414 & 115 & 27 & 1682 & 83 \\
\hline 9 & 1532 & 125 & 28 & 1692 & 82 \\
\hline 10 & 719 & 94 & 29 & 1337 & 79 \\
\hline 11 & 162 & 36 & 30 & 1804 & 84 \\
\hline 12 & 1137 & 96 & 31 & 1643 & 85 \\
\hline 13 & 663 & 96 & 32 & 1700 & 82 \\
\hline 14 & 1893 & 134 & 33 & 1689 & 82 \\
\hline 15 & 163 & 38 & 34 & 1735 & 84 \\
\hline 16 & 1238 & 110 & 35 & 4651 & 169 \\
\hline 17 & 1735 & 85 & 36 & 1582 & 83 \\
\hline 18 & 1654 & 81 & 37 & 1736 & 83 \\
\hline 19 & 1651 & 83 & 38 & 1697 & 82 \\
\hline
\end{tabular}

Table 3

Forces values at tumble turn by $360^{\circ}$

\begin{tabular}{|c|c|c|c|c|c|c|c|}
\hline Rotation angle $^{\circ}$ & $F_{x} N$ & $F_{y} N$ & $F_{z} N$ & Rotation angle $^{\circ}$ & $F_{x} N$ & $F_{y} N$ & $F_{z} N$ \\
\hline 10 & 42.85 & 788.74 & 385.91 & 190 & 74.15 & 947.06 & 627.05 \\
\hline 20 & 54.24 & 753.75 & 429.51 & 200 & 63.07 & 917.19 & 570.39 \\
\hline 30 & 49.14 & 811.55 & 445.59 & 210 & 58.79 & 896.91 & 534.29 \\
\hline 40 & 58.61 & 753.37 & 482.17 & 220 & 58.79 & 925.83 & 532.76 \\
\hline 50 & 65.89 & 796.99 & 541.69 & 230 & 56.57 & 925.45 & 508.36 \\
\hline 60 & 74.48 & 848.63 & 586.37 & 240 & 53.62 & 872.02 & 474.02 \\
\hline 70 & 82.30 & 844.33 & 608.85 & 250 & 48.77 & 876.65 & 455.86 \\
\hline 80 & 86.59 & 911.92 & 644.79 & 260 & 52.92 & 923.80 & 484.82 \\
\hline 90 & 78.49 & 822.55 & 610.43 & 270 & 51.50 & 931.28 & 476.41 \\
\hline 100 & 78.97 & 823.12 & 618.03 & 280 & 51.78 & 919.13 & 452.65 \\
\hline 110 & 78.38 & 803.06 & 612.43 & 290 & 45.76 & 863.64 & 390.71 \\
\hline 120 & 78.46 & 759.89 & 609.91 & 300 & 43.55 & 853.05 & 372.93 \\
\hline 130 & 80.76 & 787.51 & 646.16 & 310 & 43.75 & 823.88 & 364.82 \\
\hline 140 & 87.37 & 827.77 & 712.65 & 320 & 43.52 & 834.18 & 370.95 \\
\hline 150 & 85.58 & 862.50 & 697.19 & 330 & 44.10 & 812.45 & 371.69 \\
\hline 160 & 83.59 & 893.70 & 700.62 & 340 & 50.61 & 846.27 & 416.66 \\
\hline 170 & 79.76 & 948.19 & 688.09 & 350 & 51.80 & 862.26 & 431.16 \\
\hline 180 & 78.31 & 955.54 & 672.46 & 360 & 42.75 & 784.32 & 381.25 \\
\hline
\end{tabular}




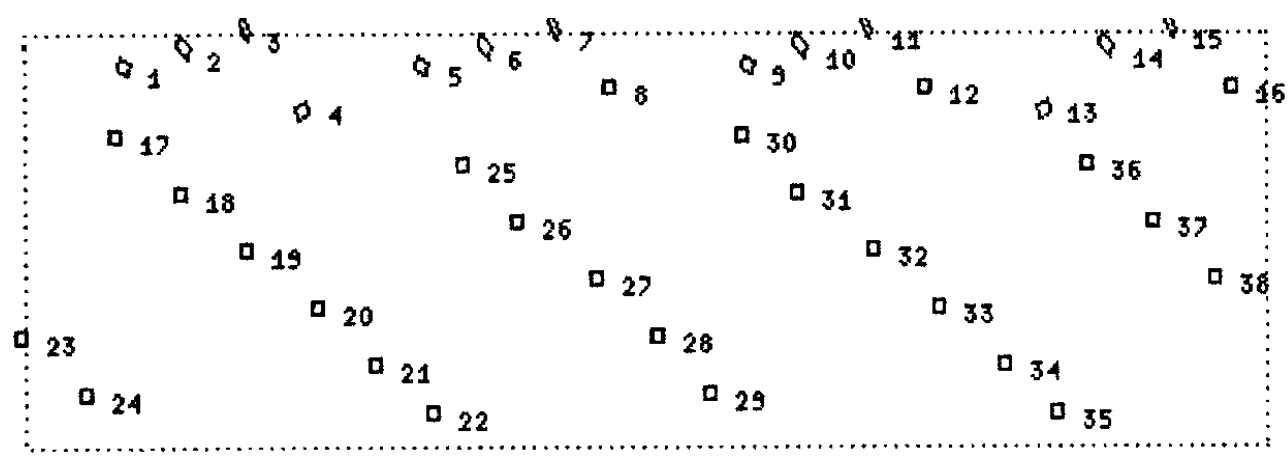

Fig. 8 Knives placement on the longwall tumble coal miner's KGS-320 mining head during its one full turn $\left(360^{\circ}\right)$

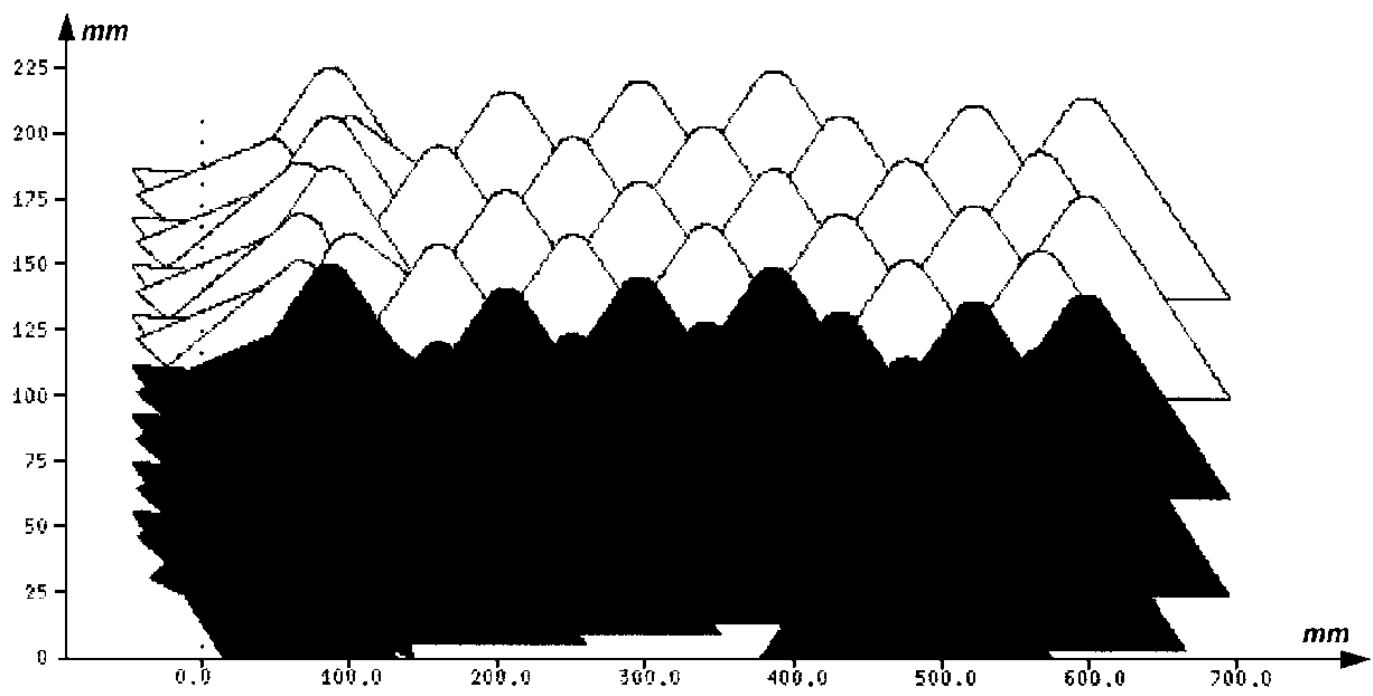

Fig. 9 Mining scheme (knives web) at tumble turn by $360^{\circ}$

Table 4

Moments values at tumble turn by $360^{\circ}$

\begin{tabular}{|c|c|c|c|c|c|c|c|}
\hline $\begin{array}{c}\text { Rotation } \\
\text { angle }^{\circ}\end{array}$ & $\begin{array}{l}\mathrm{M}_{\mathrm{x}} \\
\mathrm{Nm} \\
\end{array}$ & $\begin{array}{l}\mathrm{M}_{\mathrm{y}} \\
\mathrm{Nm} \\
\end{array}$ & $\begin{array}{l}\mathrm{M}_{\mathbf{z}} \\
\mathrm{Nm} \\
\end{array}$ & $\begin{array}{c}\text { Rotation } \\
\text { angle }^{\circ}\end{array}$ & $\begin{array}{l}\mathrm{M}_{\mathrm{x}} \\
\mathrm{Nm} \\
\end{array}$ & $\begin{array}{l}\mathrm{M}_{\mathrm{y}} \\
\mathrm{Nm} \\
\end{array}$ & $\begin{array}{l}\mathrm{M}_{\mathbf{z}} \\
\mathrm{Nm}\end{array}$ \\
\hline 10 & 518.13 & 61.50 & 184.77 & 190 & 708.00 & 184.17 & 217.30 \\
\hline 20 & 529.15 & 78.68 & 168.16 & 200 & 669.54 & 163.10 & 211.96 \\
\hline 30 & 562.10 & 76.51 & 183.11 & 210 & 649.49 & 154.82 & 210.40 \\
\hline 40 & 563.68 & 82.86 & 150.32 & 220 & 673.41 & 142.04 & 210.20 \\
\hline 50 & 615.62 & 102.08 & 166.68 & 230 & 668.33 & 118.68 & 200.76 \\
\hline 60 & 644.99 & 129.61 & 185.90 & 240 & 621.43 & 101.76 & 184.39 \\
\hline 70 & 645.99 & 145.50 & 194.68 & 250 & 602.22 & 94.06 & 199.39 \\
\hline 80 & 681.22 & 167.97 & 227.29 & 260 & 635.47 & 87.61 & 204.44 \\
\hline 90 & 638.04 & 178.50 & 209.45 & 270 & 631.09 & 77.52 & 198.06 \\
\hline 100 & 647.29 & 183.97 & 209.75 & 280 & 606.93 & 65.20 & 194.47 \\
\hline 110 & 635.53 & 180.85 & 192.79 & 290 & 537.98 & 49.01 & 185.83 \\
\hline 120 & 623.44 & 174.12 & 173.91 & 300 & 516.60 & 49.36 & 191.32 \\
\hline 130 & 654.11 & 182.15 & 174.72 & 310 & 499.52 & 45.63 & 186.67 \\
\hline 140 & 704.32 & 206.58 & 188.99 & 320 & 509.04 & 47.57 & 185.71 \\
\hline 150 & 726.60 & 205.91 & 197.81 & 330 & 507.12 & 49.52 & 176.49 \\
\hline 160 & 740.53 & 218.42 & 209.94 & 340 & 548.79 & 56.27 & 181.94 \\
\hline 170 & 754.82 & 213.58 & 224.94 & 350 & 569.67 & 61.60 & 192.89 \\
\hline 180 & 746.29 & 203.86 & 224.01 & 360 & 511.24 & 63.85 & 182.94 \\
\hline
\end{tabular}




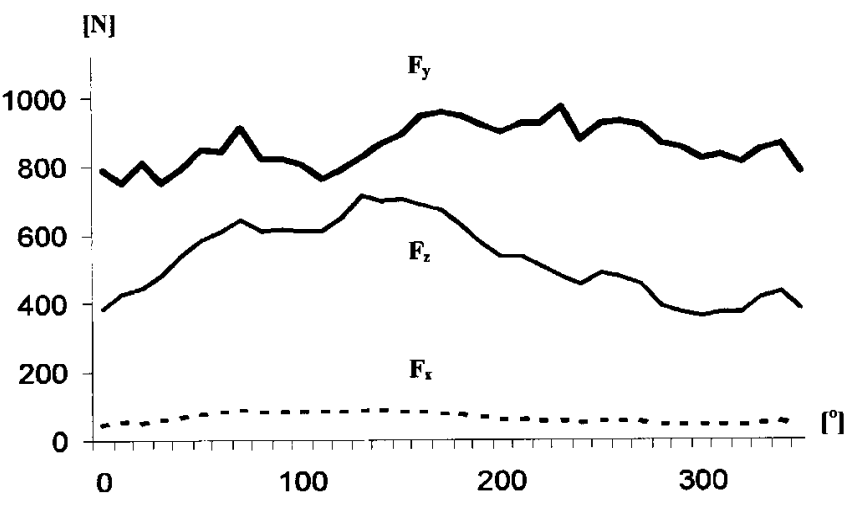

Fig. 10 Force characteristics during one full turn $\left(360^{\circ}\right)$

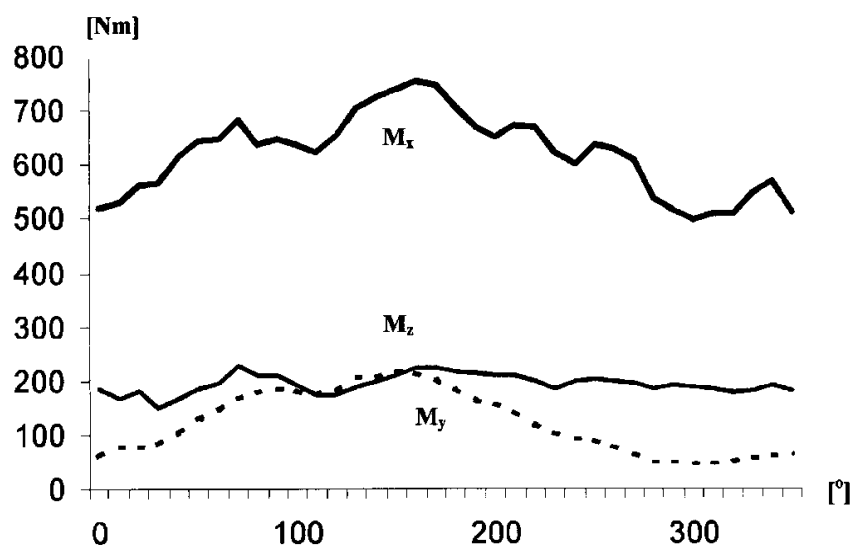

Fig. 11 Moments characteristics at one full turn $\left(360^{\circ}\right)$

\section{SUMMARY}

The above-discussed problems regard the solid coal mining with application of longwall tumble coal miners' mining organs. The mining technology presented is currently, and in the nearest future, the only effective and profitable coal mining method in Poland and worldwide therefore it is so important to determinate the forces and moments values which may occur on the longwall tumble coal miner's mining head.

The experiments performed allowed to estimate the influence of the mined solid coal properties on forces and moments values occurring on the mining head of the longwall coal miner.

Based upon performed experiments we are allowed to:

- determinate the mining scheme which provides us with the information on the given knives' mining mode. The above analysis leads to selection of the knives that are overloaded during the mining process as well as the knives, which have minimal share or do not take part in this process at all. The scheme shows all mining organs' imperfections, which are quite often seen in real-life conditions, resulting from their construction or production.

The optimal knives placement must result from the knife's uniform load during one full turn of the mining organ's tumble criteria. The proper and thorough analysis of the problem influences the proper knives' placement in the most loaded places of the mining organ. Proper selection of $\beta_{1}$ angle is very important as well so the side contact of the knife with the mined solid coal would be avoided ( $F_{b}$ force). The placement of the knives on the cutting disk is an underestimated problem. The performed analysis should be concluded that the highest differences in the web areas (loosening lines) of given knives are on the cutting disk (Table 2). The vital problem is proper transition from the knives placement on the cutting disk to given snail's lobes in such way that any fragment of the solid coal would not be mined with any knife placed on the cutting disk. It does also influence the non-uniform knives wear during the mining process, with the costs accompanying, and the dynamics of the whole mining process, too,

- determinate the forces and moments characteristics during the mining process. Forces and moments resulting from: the knife's placement on the mining organ, mineability index $A$ value and side-crumble angle $\psi$ of the mined coal, have a strong influence on the mining organ action's dynamics also - the whole coal miner's unstable performance.

The forces and moments characteristics of the longwall tumble coal miner's mining organ during its one full turn are presented on figures 11 and 12 . The analysis of the curves $\left(F_{x}, F_{y}, F_{z}, M_{x}, M_{y}, M_{z}\right)$ shows further mining organ's lacks. At one full turn of the mining organ $\left(360^{\circ}\right)$ the variabilities of forces and moments values show strong aberrations from the mean values, consequently $F_{x}$ forces varies from $42.75 \mathrm{~N}$ to $87.37 \mathrm{~N}, \mathrm{~F}_{\mathrm{y}}$ from $753.37 \mathrm{~N}$ to $955.54 \mathrm{~N}$, while $F_{z}$ reaches values between $364.82 \mathrm{~N}$ and $712.65 \mathrm{~N}$ (Table 3 ). The moments vary within the following ranges: $\mathrm{M}_{\mathrm{x}}$ from $507.12 \mathrm{Nm}$ to $754.82 \mathrm{Nm}, \mathrm{M}_{\mathrm{y}}$ from $45.63 \mathrm{Nm}$ to $218.42 \mathrm{Nm}$ and $\mathrm{M}_{\mathrm{z}}$ between $150.32 \mathrm{Nm}$ and $227.29 \mathrm{Nm}$ (Table 4).

Theses values show the dynamics of the longwall tumble coal miner's mining head's load as well as the whole machine.

The result of the performed analysis is a conclusion that there are several lacks in the knives placement on the mining organs - regarding the coal miner's dynamics of action the solutions are imperfect.

The solution of the stated problem is a situation where all forces and moments would vary as little as possible from the mean values - the mining organ's action would be stable what has a direct relation to coal miner's mining dynamics (mining process).

\section{REFERENCES}

[1] W. Biały. "Volba dobývacích kombajnů na základě výzkumů rozpojitelnosti uhlí". VŠB-TU Ostrava, Fakulta strojní Ostrava 2009. ISBN 978-80-248-2032-3. p. 120.

[2] W. Biały. „Zasoby węgla kamiennego. Urabialność pokładów węglowych". Wydawnictwo PA NOVA SA. Gliwice 2014. ISBN 978-83-937845-5-4. p. 150

[3] W. Biały. „Innowacyjne narzędzia do wyznaczania właściwości mechanicznych węgla"in Przegląd Górniczy vol. 6/2013. Katowice. ISSN 0033-26X. pp. 17-26.

[4] W. Biały. „Problémy rozpojitelnosti uhlí a hornin“ in Technická Diagnostika vol.1 ročnik XXII 2013. CZECHY. ISSN 1210-311X. CD s. 41-50.

[5] W. Biały. „Innovative solutions applied in tools for determining coal mechanical proprerties" in Management Systems in Production Engineering vol. 4 (20)/2015. Gliwice. ISSN 2299-0461. pp. 202-209. DOI: 10.12914/MSPE-02-04-2015

[6] J. Borycz, A. Kozieł. "Wpływ koncentracji naprężeń w górotworze na wybrane parametry eksploatacji ściany węglowej", in Międzynarodowa Konferencja „KOMTECH 2000" „Efektywne prowadzenie wyrobisk w trudnych warunkach górniczo geologicznych", Szczyrk, 2000 XX pp 1-13. 
[7] B. Drzęźla. „Dlaczego kopalnie powinny pracować siedem dni w tygodniu?" in Trybuna Górnicza, 25 (406)/2002.

[8] B. Drzęźla. „Dlaczego siedem dni w tygodniu?” in Trybuna Górnicza, 32(413)/2002.

[9] A. Karbownik, E. Pawełczyk. „Podstawowe założenia i elementy reformy górnictwa węgla kamiennego w latach 1998-2002" in Mechanizacja i Automatyzacja Górnictwa, vol. 5/1998. ISSN 0208-7448. pp. 38-42.

[10] P. Pużyński, S. Starzyński. „Reforma górnictwa na lata 2003-2006". in Gazeta Wyborcza, 156(4064)/2002.

[11] W. Sikora. „Ściana o wysokiej koncentracji produkcji w perspektywie roku 2000" in Nowoczesne techniki i technologie w podziemnej eksploatacji złóż - systemy eksploatacji węgla o dużej koncentracji wydobycia. Szczyrk 1995.
[12] W. Sikora. „Zapotrzebowanie mocy w przodkach ścianowych $w$ aspekcie intensyfikacji i koncentracji produkcji" in Mechanizacja i Automatyzacja Górnictwa, vol. 1/1997. ISSN 0208-7448.

[13] W. Sikora. „Wpływ koncentracji produkcji na restrukturyzację techniczną polskiego przemysłu węglowego" in Międzynarodowa Konferencja Naukowo-Techniczna „Kompleksy ścianowe o dużej koncentracji wydobycia w warunkach technicznej restrukturyzacji polskiego górnictwa". SITG-CMG"KOMAG" Gliwice-Szczyrk 1999.

[14] J. Vasek, J. Slavik, H. Gondek. Analiza poprawy pracy organów urabiających kombajnów chodnikowych i ścianowych przy pomocy modelowania matematycznego" in XXVII Sympozjum "Modelowanie w mechanice" Gliwice-Wisła 1988.

dr hab. inż. Witold Biały, prof. Pol. śl.

Silesian University of Technology, Faculty of Management and Organization

Institute of Production Engineering

ul. Roosevelta 26, 41-800 Zabrze, POLAND

e-mail: wbialy@polsl.pl 